\title{
Meta Analysis of Women Politician Portrait in Mass Media Frames
}

\author{
HASAN SAZALI \\ Universitas Islam Negeri Sumatera Utara, Indonesia \\ LUTFI BASIT \\ University of Muhammadiyah Sumatera Utara, Indonesia
}

\begin{abstract}
In every discourse on women, the issue of gender equality and how the involvement of the media in the struggle for gender equality always arises. This issue occurs not only in countries that are not yet democratically established, but also in countries that have had established democratic systems. This study aims to describe the portrait of women politicians in a mass media frame. The portrait was examined based upon the results of previous studies using meta-analysis methods. The unit of analysis used in this study is written documents obtained from the result of a research on women politicians and mass media in the form of journal articles and research reports taken purposively by adjusting them to the research theme. This study uses quantitative data analysis with percentages and qualitative data analysis for data obtained from the results of a narrative study of the researches that were found. The results show that the media in America, Europe, Africa, and Asia, with different levels of democratic establishment, have treated female politicians in the same way as male politicians, by framing female politicians negatively and applying standards that are detrimental to women. Women politicians are presented by the media in terms of gender and femininity instead of ability, strength of vision, and competence in politics. Portraits of women in the frame of the mass media are still blurred in America, Europe, Africa and Asia.
\end{abstract}

Keywords: Meta analysis, gender, women politicians, frame, mass media.

\section{INTRODUCTION}

The mass media is one of the milestones in the development of human life. Mass media or press is a term that began to be used in the 1920s to term a type of media specifically designed to reach a wide, instantaneous, and heterogeneous audience. In everyday conversation, the term mass media is often abbreviated to just the media. Marshall McLuhan (1964) called the mass media the extension of man. The mass media has a significant role to provide information, disseminate opinions, build perception, and even construct reality.

McNair (1995) more pointedly stated that mass media in political reality can take on three roles; First, the media acts as an intensifier, the media are able to bring up issues and sharpen them. Issues raised by the media will reveal the dimensions of the issue sharply. The media blows up the reality of the issue so that all dimensions of the issue become transparent. Second, the media as a conflict diminisher, the media sinks an issue. The media intentionally negates the issue, especially when it concerns the interests of the media, both ideological and pragmatic interests. Third, the media as a director of conflict resolution, the media becomes a mediator by presenting issues from various perspectives and directing conflicting parties by presenting issues from various perspectives and directing conflicting parties to conflict resolution (McNair, 1995). 
With such a large capacity, the media has the potential to have an impact on the formation and evolution of social and cultural norms, including connecting social and cultural norms with women. At the same time, the image of women and the role that women play in the media are strongly influenced by existing social and cultural norms.

Every discourse about women always raises the issue of gender equality and the involvement of the media in the struggle for gender equality. Gender equality is not merely echoed in countries that are not yet democratically established, but even in developed countries with an established democratic system, gender issues have never been extinguished.

Gender justice is an issue that was intensively discussed since 1975 at the World Conference on women in Mexico, Copenhagen, Nairobi, until the Conference in Beijing in 1995. In 1995, the fourth World Conference on Women in Beijing produced a platform known as Beijing Platform for Action.

Platform for Action focuses on twelve critical areas, namely (1) Women and Poverty; (2) Women and Education; (3) Women and Health; (4) Violence against Women; (5) Women and Armed Conflict; (6) Women and Economy; (7) Women in Power and Decision Making; (8) Institutional Mechanisms for Advancing Women; (9) Human Rights for Women; (10) Women and Mass Media; (11) Women and the Environment; and (12) Girls (unwomen.org., 2015).

Interestingly, from the twelve platforms for action there is a focus that directly links women and politics. As a logical consequence, in various discourses there is a strong push for women to get actively involved in the political sphere with the aim of becoming members of parliament. Women need sufficient representation in parliament to be able to fight for the issuance of legislation products and policies concerning women that refer to the twelve critical areas as the focus of the platform for action. The United Nations revealed that women's representation must reach at least 30 percent in parliament to allow for a change to occur and have an impact on the quality of decisions taken in public institutions.

Women's representation in parliament in Europe that promotes gender involvement in the political sphere has not been by far evenly distributed. There are still countries where women are under-represented in parliament. After 25 years, the average representation of women in European countries' parliament stands at 30.2\%-36.1\%. Some countries saw high representation of women in parliament, such as Finland (76.9\%), Croatia and Ireland (both at 54.5\%). However, it is still low in several other member countries, such as Estonia and Cyprus (both at 16.7\%) and Bulgaria (17.6\%). Interestingly, Malta, whose gender equality is almost the lowest compared to other EU member states, has a gender balance in the European Parliament, with $50 \%$ of its members being women (Kumar, 2017).

According to Kumar (2017), in some African countries, women have high representation in parliament, such as Rwanda (55.6\%), Senegal (41.8\%), and South Africa $(41.2 \%)$, whereas in most Asian countries women's representation in parliament is very low, such as Benin (7.2\%), Maldives (5.9\%), Sri Lanka (5.8\%), Nigeria (5.7\%), Thailand (4.8\%), Kuwait (31\%), Lebanon (3.1\%), Haiti (2.7\%), Yemen (0.51\%), and Qatar (0\%). In Indonesia, a total of 117 women were inaugurated as members of the House of Representatives (DPR) for the 2019-2024 period, representing $20.3 \%$ of the overall DPR members at 575 . Even in DKI Jakarta, in Umaimah Wahid 's research, women's power in politics was still very low compared to that of men who had dominated politics (Umaimah, 2013). 
The result of a research conducted on women's representation shows that women's representation in parliament worldwide in 2017 accounted for only 23.3 percent of the total seats. In some countries, the representation of women is very high, while in other countries it is still very low.

Building an egalitarian society, without distinguishing between men and women, is one of the priorities of modern democracies. The media as the fourth pillar of democracy plays a unique and important role in shaping a society where men and women can enjoy the same rights, but the role of the media is considered not to be maximal (Ritonga et al., 2018; Fitriyah et al., 2019). A number of international conferences and conventions were held, voicing and publicising the need to break public stereotypes through changes in media policy.

The mass media is considered to still reproduce discriminatory stereotypes about women and portray them in sexist ways. Women are depicted in a narrow range of characters in the mass media. If the mass media is divided into two categories, such as fiction and news reporting, then in the first category, women are often associated with household or sex objects, and in the latter category, they have no role.

A research conducted by the Council of Europe states that studies in Europe regularly look into media coverage of elections through a gender lens and the findings show that men are more visible and that women are subject to discrimination (Council of Europe, 2017).

Shafiul Islam (2016), in his research of 130 coverages from three TV stations in Bangladesh, found that the report was dominated by male gender. Kaul (2012), in his study, saw that when the media covered women in a biased then impacted on a bad image and hindered their development in society, the media reasoned that this was a demand of society.

The results of this study strengthen the symbolic annihilation theory of Gaye Tuchman (1978) who revealed the way the mass media ignored women as subjects and sources of news, and underestimated their political contributions through trivialisation and punishment (Fountaine \& McGregor, 2002). McQuail (2005) argued that media framing in communication research can be studied in two ways; individual frame and media frame. The individual framework is related to individual cognition or understanding of certain situations. Norris (1997) uses the concept of a "gender framework" to illustrate how journalists utilise conventional contexts to "simplify, prioritize, and compile a narrative flow of events when covering women and men in public life" (p.6).

Rajaratnam and De Rycker (2018) found something different in his research that media coverage of female candidates in Malaysia underwent a positive development in the 2013 general election compared to the general election five years ago (2008). Female candidates are positioned as competent professionals.

Rahman et al (2015) in his research on Framing of Women in Politics: A Case of Pakistani Elections 2013 concluded that It cannot be denied that the way women in politics displayed by the media is not necessarily able to change their status and image, but it will be a step in the right direction. In addition to the media, other social and political institutions must also play a role in creating discourse about women who are empowered to change their image both in society and in the media (Rahman et al., 2015).

The phenomenon as described above triggers the desire to study the portrait of women politicians in a mass media frame through meta-analysis. This study aims to describe the portrait of women politicians in a mass media frames. 


\section{Female Politicians and Media}

\section{LITERATURE REVIEW}

Are women suited to become politicians or get involved in politics? Such a question is still heard, though not so loud, in some communities because, in reality, only a few women have held important political positions. The question is also something natural because the political world is very competitive, a fact that is also suspected of being the reason behind the lack of women's representation in politics compared to men's. The image that the political world is hard, dirty, and full of intrigue reinforces the notion that the political world is identical to men. In turn, the number of women involved in politics is relatively small, even in countries whose democratic systems and equal rights are already established. Women are always portrayed with tasks to prepare family needs at home, such as cooking, taking care of children, and serving their husbands (Zamroni, 2013).

The media as one of the pillars of democracy has an important role in how women are depicted in a political context. The media is an important measurement tool to find out how society views women. The mass media is able to 'force' the public to draw attention to certain issues. The media constantly presents objects that show what people have to think, know, and feel to create an image, including what the media do to female politicians.

The study of how the media portrays female politicians in Western countries consistently shows that the media portrays male and female politicians differently by emphasizing the feminine personal nature of female politicians, as well as their lack of experiences and qualifications in the political field. Female politicians are not represented because of their political participation, policy making, strategy, vision, and contribution to decision making. A study conducted by Kaul (2012) on Globalization and Gender Issues revealed that over the years, research on gender depiction consistently revealed a pattern that men appear in roles with higher status, while women mainly appear in lower status roles (Kaul, 2012).

Women politicians often protest against the non-serious attitude of media coverage about women politicians, this is reflected not only in the portion of coverage given to women which is less than the portion given to men but also in the way they are described (Kahn, 1994).

The focus of early research on the representation of women politicians in the media was on visibility because women politicians received far less news coverage than men (Tuchman, 1978).

Visibility becomes one of the interesting topics in each discourse related to media coverage of female politicians, namely the level of attention the media gives to them. In a broader sense, visibility not only implies the amount of coverage, but also how the press frames the coverage. It is a fact that a woman is clearly related to the frame in which she is made visible. Although the quantity of coverage is an easily measured indicator because it is related to the number of men, interpreting the quality of coverage is a far more complex task because it is subject to finer gender constraints. The visibility of female politicians has been analysed by a number of studies by Devitt (1998) and Bystrom et al. (2004) (Campus, 2013). Although based on a few exceptions, the emerging trend is that women are becoming more visible in terms of coverage than in the past.

Gaye Tuchman's theory of how symbolic annihilation applies to mass media representations is perhaps the most quoted work on the issue of visibility (Fountaine \& McGregor, 2002). The term symbolic annihilation was used by Tuchman to describe the way the mass media ignored women as subjects and sources of news, and underestimated their 
political contributions through trivialisation and punishment. In many studies, Kahn and Goldenberg (1994) found evidence that supported Tuchman's assessment because female political candidates were featured in far less news than male political candidates (Kahn, 1994).

In other studies of women in politics, they point out that the media treat women in politics differently from men (Van Zoonen, 2006). Van Zoonen (2006) found that women politicians only had limited choices in politics. In other words, "they need to mask their femininity and imitate men, otherwise accusations of being frivolous, coquettish and - worst of all - loose, will be their lot. The only feminine model of celebrity available to women in politics would be that of the mother, tying into myths of femininity as nurturing and caring" (p. 292).

Jeremy Bentham's Panopticon can be used as a metaphor to illustrate how control and supervision exercised on a woman's body from the outside tends to stimulate action automatically, from within, once a certain feminine ideal has been internalised. The media defines femininity in relation to beauty and youth, because these are the dominant values in contemporary culture (Damean, 2006).

Michel Foucault defines the panopticon as an extremely efficient monitoring and control instrument that exists in all modern institutions (Foucault, 1997). In the panopticon, the observer can see without being seen, while what is observed is permanently exposed. The control object is aware of its permanent visibility and therefore complies with all the rules. Because individuals can never see their observers, they never know whether they are really being watched. This mechanism provides an automatic effect of power, causing the observed to be their own submission principle (Damean, 2006).

External supervision becomes self-monitoring so that other external obstacles are no longer needed. As for the woman's body, it is enough for the woman to internalise that she is the object of a masculine gaze so that she can obsessively control and observe her movements, posture, and appearance. The practices that women use to stay beautiful ideally affect their physical health and, because standards of femininity are difficult to reach, women are forced to live most of their lives with feelings of lack, not good enough, which means that severe control of the body can also affect mind. As can be seen, the main concepts of media discourse are "supervision" and "control" over women's bodies, both external and internal. The media uses this strategy to shape women's bodies and also to shape their social roles.

A research conducted by Stellarosa (2017) on the image of women from the book Miss Jinjing Shopping Until Death shows that women are portrayed as consumptive figures, connoisseurs, lovers and shopping enthusiasts. According to him, the media shaped the image of such women as a reflection of the identity of capitalism. The media presents excessive reality about lifestyle and the world of shopping for women with the aim of controlling them so that they will voluntarily achieve the hypereality that has been formed by the system of capitalism (Stellarosa, 2017).

\section{Media Framing and Gender Marginalization}

The concept of a gender system is central to feminist theory. According to Yvonne Hirdman (1990), the gender system is built on two logical assumptions, the first is gender segregation (difference) and the second is male dominance or norms (hierarchy). This logic is then enforced by what Hirdman (1990) metaphorically calls a gender contract, which states that women and men are born into and shaped by the gender system. 
There are several different terminologies used in the debate when explaining gender differences in media representation. Khan (1996) uses the concept of 'sex stereotypes' which are defined as "cognitive structures of inferential relationships that incorporate personal attributes, behaviors, and beliefs into the social categories of men and women" (Khan, 1996, p.6), whereas Norris (1997) uses the concept of a "gender framework" to illustrate how journalists utilise conventional contexts to "simplify, prioritize, and compile a narrative flow of events when covering women and men in public life" (p.6). Chang and Hitchon (1997) developed the idea of a 'gender scheme' to refer to the conceptual cognitive structure that people use to understand "traits, activities, and behaviors that have traditionally been associated with men or women" (p. 35). Gender differences in media representation will be clearly seen from the way the media frame it.

This analysis of media framing is often traced to Erving Goffman in his main work entitled "Framing analysis: An essay on the organization of experience" in 1974. Framing is one of the media effect theories, which is mostly used to analyse how mass media filters information and, thus, influences public reaction to a series of external stimuli. This framing theory makes the media have the ability to promote certain news items through actions or techniques such as selection, emphasis, exclusion, and elaboration (Scheufele \& Iyengar, 2014; Oyewole \& Olisa, 2017).

Gamson (Fauzi, 2007) with a constructivism approach sees framing as a process of social construction in interpreting reality. This process occurs on two levels, namely the individual or interpretative level and the level of discourse or culture. These two levels are interrelated in the process of social construction to make sense of reality. In this context, Gamson sees a relationship between media discourse and public opinion formed in society.

At the level of discourse or culture, the frame gives clues as to what elements of the issue are relevant in the discourse, what issues require political action and what solutions must be taken, and which parties are suitable in the discourse that is formed. At the individual or interpretative level, individuals act consciously, rationally, and intentionally because they always include experiences, social insights, and psychological in interpreting the message received. It is this crystallized experience and knowledge that selects to map, receive, identify, and label the events or information received.

Gamson and Modigliani (Fauzi, 2007) define the frame as a way of telling story lines or groups of ideas organised in such a way and presenting the construction of meaning or events related to the object of a discourse. Framing can also be interpreted as placing information in a specific context so that certain issue elements get a greater allocation in individual cognition than other issue elements.

McQuail (2005) argued that media framing in communication research can be studied in two ways; individual frame and media frame. The individual framework is related to individual cognition or understanding of certain situations.

Current media owners are generally profit-oriented so they will provide candidates with a favorable offer. As a result, inadequate media attention can be a factor of gender inequality in politics.

Women politicians are treated with a systemic bias by the media and have news value only when they have aggressive behaviour which once again contradicts traditionally perceived gender roles. That is why politics is considered a male domain (Rahman et al., 2015).

Norris (1997) found that, overall, women leaders in politics received less coverage than men, and that the news media highlighted the lack of political experience, expertise, and qualifications among female leaders by constantly referring to them as people the outside. At 
the same time, headlines and guidance on women's leadership tend to focus on women's breakthroughs while highlighting the role of women leaders as agents of change in fighting political corruption (Norris, 1997). According to Norris (1997), even though the difference between genders is simple, female leaders receive less press attention than men.

Another theme in analysing coverage of female politicians is the contrast between coverage that focuses on personal traits and coverage that focuses on the central issue. Much evidence supports the general belief that gender, marital and parental status, and physical appearance are considered more valuable at the expense of serious discussion about their policies (Campus, 2013).

This gender framing of media makes voters evaluate both the leadership and ability of women in politics differently from men (Norris, 1997). It cannot be denied that the way women in politics are displayed by the media would not necessarily be able to change their status and image, but it will be a step in the right direction. In addition to the media, other social and political institutions must also play a role in creating discourse about women who are empowered to change their image both in society and in the media (Rahman et al., 2015).

\section{METHODOLOGY}

This research uses a meta-analysis design. A simple meta-analysis can be interpreted as an analysis of the analysis. As a research, meta-analysis is a study of a number of research results in a similar problem. After the focus of the research becomes clear, simple research instruments will be developed, and are expected to complement the data and compare data that has been found previously. The documentation technique is used for data collection techniques. The research subject is a research document that has been conducted and determined purposively, namely research with a focus on media studies and women politicians. The determination is based on its suitability to the theme of this study.

There are as many as 15 studies which are relevant to the theme used as a unit of research and taken from several countries from 4 different continents, namely America, Europe, Africa, and Asia. The studies were obtained from various sources, such as articles (research results) in research journals and research reports. In general, the data is obtained by downloading from the internet.

The research units are (1) Research conducted by Caroline Fox on Bound: Print Journalism's Framing of Female Candidates in the 2008 Presidential Race According to the 'Double Bind' Theory (Fox, 2010); (2) Núria Fernandez-Garcia's research on framing gender and women politicians representation: print media coverage of Spanish women ministers (Fernandez-Garcia, 2016); (3) Research by Bushra Hameedur Rahman et al. with the title Framing of Women in Politics: A case of Pakistani Elections 2013 (Rahman et al., 2015); (4) Research by the Zimbabwe Media Monitoring Project on Media Representation of Women in Politics (Matingo, 2012); (5) Åsa Kroon Lundell and Mats Ekström's research on The Complex Visual Gendering of Political Women in the Press (Lundell \& Ekström, 2008).

Other studies that are part of the meta-analysis unit are (6) Shafqat Munir et al.'s research on Media Analysis of Women's Participation in Politics (Munir et al., 2014); (7) Misni Astuti's research entitled Social Media Construction Against Tri Rismaharini's Personal Branding Power in the Process of Contemporary Political Communication (Astuti, 2016); (8) Bushra Hameedur Rahman research with the topic of Analysis of the Coverage of Muslim Political Women in Time and Newsweek (Rahman, 2010); (9) Azman Azwan Azmawati's research on Women, Politics and The Media (Azmawati, 2017); (10) Lee Jinah and Lee 
Kwangho's research on Gendered Reactions to Women Politicians in Japan: The Role of Media Use and Political Cynicism (Lee \& Lee, 2016); (11) Martina Topic and Etajha C. Gilmer's research entitled Hillary Clinton and the Media: From Expected Roles to the Critique of Feminism (Topic \& Gilmer, 2017); (12) Archana Kumari and Himani Joshi's research entitled Gender Stereotyped Portrayal of Women in the Media: Perception and Impact on Adolescent (Kumari \& Joshi, 2015); (13) Taylor Blair Johnson's research on Waves of Feminism and the Media (Johnson, 2017); (14) Innocent Ihechu et al.'s research on Media Coverage and Framing of Cultural Practices that Target Nigerian Women (Ihechu et al., 2017); and (15) Sarah Allen Gershon's research entitled Media Coverage of Minority Congresswomen and Voter Evaluations: Evidence from an Online Experimental Study (Gershon, 2012).

Analysis of the data used is the analysis of quantitative data with percentages and analysis of qualitative data for the data of the results of the narrative study of the studies found.

\section{Meta Analysis Based on Research Objectives}

\section{RESULTS AND DISCUSSION}

Research objectives related to female politicians and the media revolve around the relationship of feminism and the media, examining the relationship of women politicians with the media, examining voter perceptions about female politicians, describing the personal branding power of female politicians, exploring changes in patterns and media messages towards women in politics, assessing media commitments as a platform for equality between men and women, analysis of media treatment of female politicians, and analysis of framing of female politicians. Based on a review of 15 studies the following percentage data can be generated in the following Graph 1:

\section{Graph 1: Based on Research Objectives}

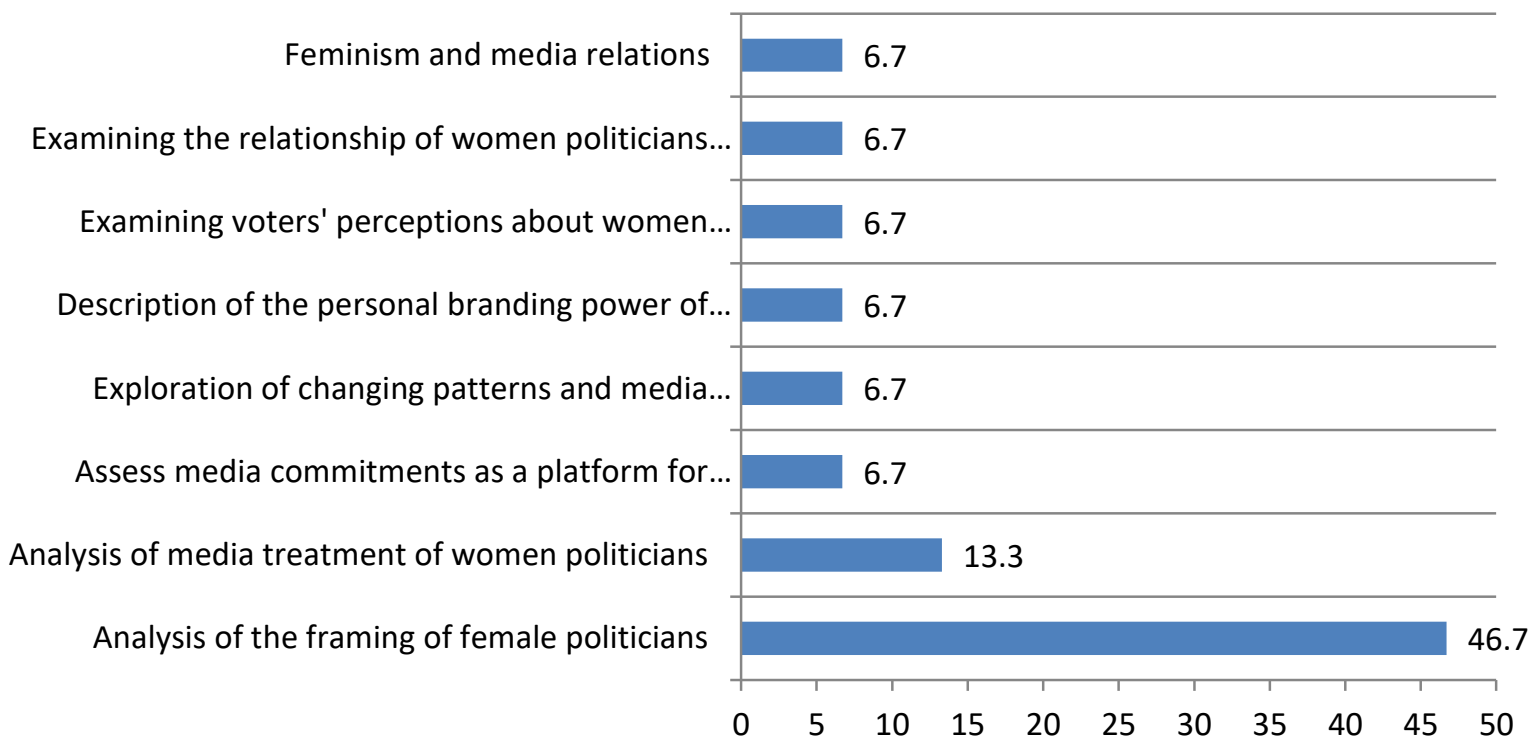

\section{Meta Analysis Based on the Analysis conducted}

The analysis used in the research that is the subject of the research unit includes framing analysis, content analysis, quantitative and qualitative analysis, semiotics, and discourse analysis, as shown in Graph 2 below: 
Graph 2: Based on Analysis

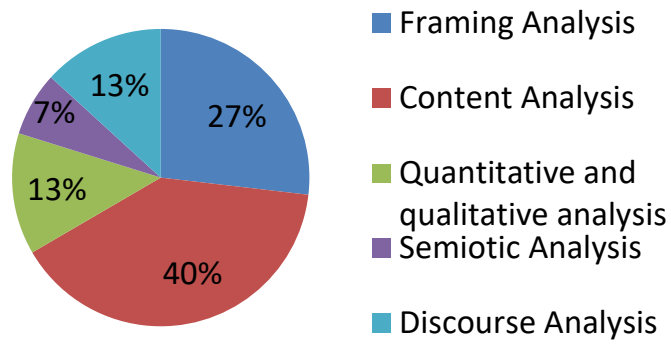

Meta Analysis Based on the Type of Media Research Subjects

In this research, the research subject is mass media. Some types of media that are subject to research are Newspapers, TV, Tabloids, Magazines, and Online Media, as shown in Graph 3.

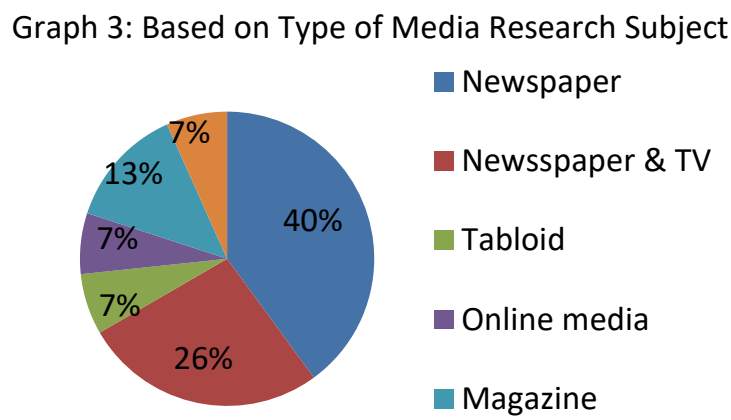

Meta Analysis by Country of Study Location

Viewed from the countries where the research is carried out, it can be categorised into four continents, namely America, Europe, Africa, and Asia, as shown in Graph 4.

Graph 4: Based on Country of Research Location

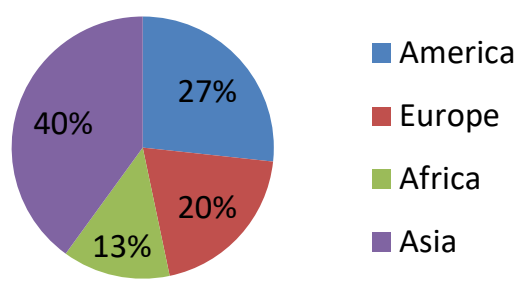

Meta Analysis Based on Research Results

Based on research conducted in several countries in America, Europe, Africa, and Asia, the results of research can be seen from the picture as follows: 


MEDIA IN AMERICA
a. Coverage of women continues to increase
b. Apply a different standard from men
c. The media destroys liberal feminism with a specific purpose
d. Women are negatively covered

Figure 1: Media coverage of women in America

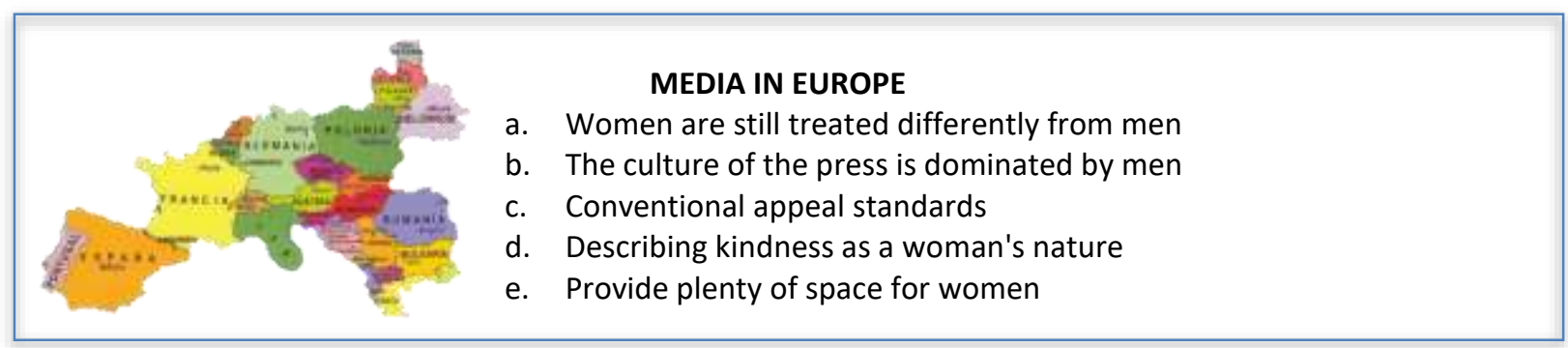

Figure 2: Media coverage of women in Europe

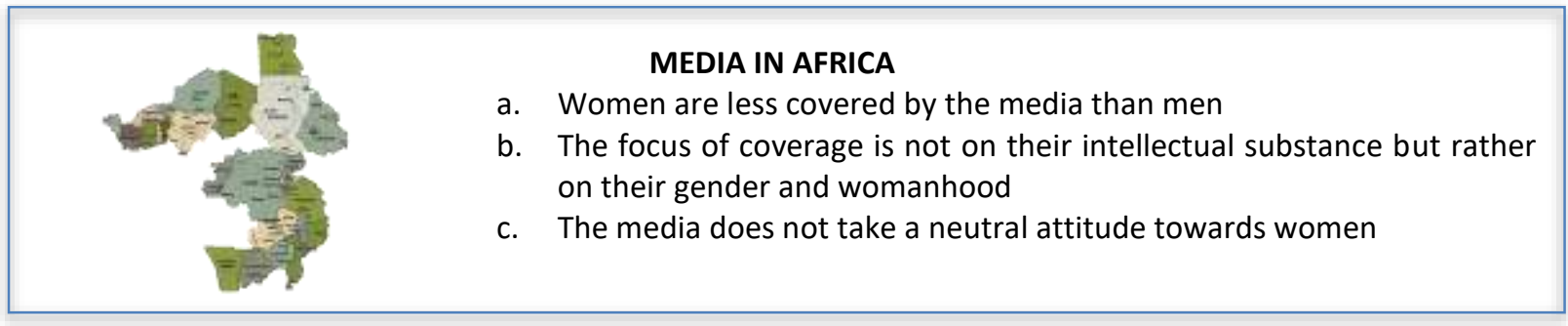

Figure 3: Media coverage of women in Africa

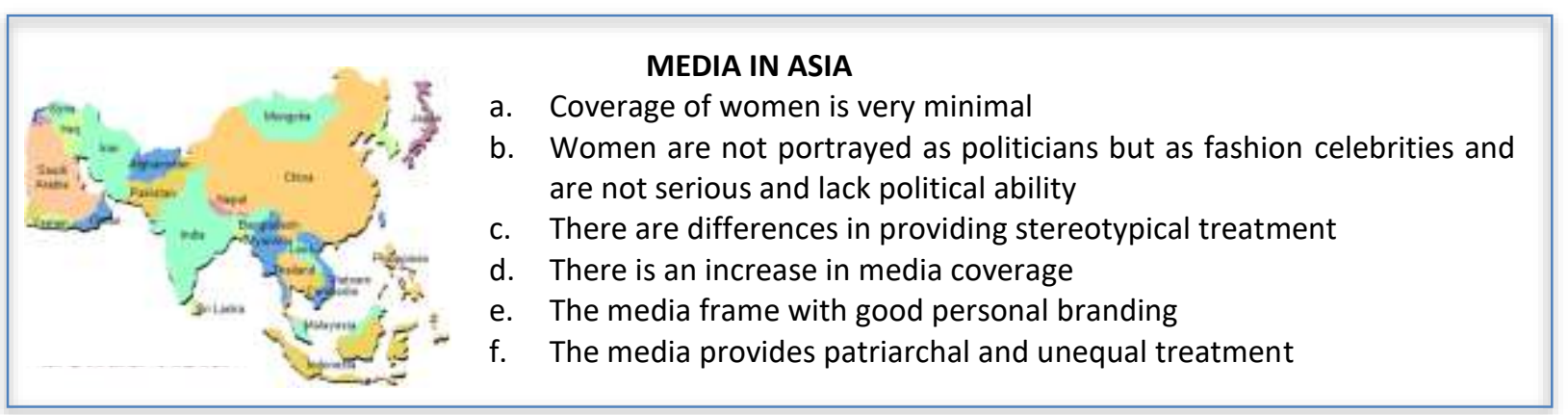

Figure 4: Media coverage of women in Asia

The research using this meta-analysis takes the setting of several countries in 4 different continents; America, Europe, Africa and Asia. Viewed from the 2018 democracy index released by the Economist Intelligence Unit (EIU) on its website, it was found that 5 topranked countries were Norway (9.87), Iceland (9.58), Sweden (9.39), New Zealand (9.26), and Denmark (9.22) (www.eiu.com., 2019). Four of the top-ranked countries are located in Europe and 1 country is located in Oceania, including the continent of Australia. EIU also featured 5 countries with the lowest democratic indexes: Chad (1.61), Central African Republic (1.52), Democratic Republic of the Congo (1.49), Syria (1.43), and North Korea (1.08). The countries with the lowest democratic index are located in Africa and Asia. 
The democratic index is directly in proportion to the 2019 press freedom index. Reporters Without Borders released 5 top-ranked countries in the 2019 World Press Freedom Index. They are Norway (7.82), Finland (7.90), Sweden (8.31), the Netherlands (8.63), and Denmark (9.87) (https://rsf.org., 2019). All the countries with the highest index of press freedom are located on the European continent. Meanwhile, five countries have the lowest ranking, namely Vietnam (74.93), China (78.92), Eritrea (80.26), North Korea (83.40), and Turkmenistan (85.44). The five countries with the lowest scores in the press freedom index are located in Asia and Africa.

The most widely used mass media to find out portraits of women politicians is newspaper. Compared to other media such as TV, magazines, tabloids, online media, and magazines, newspaper has advantages. Newspaper can really dig deep into stories in ways that television news broadcasts cannot. In newspaper, the story can be completely refined, providing all information relevant to the story and adding direct quotes from sources that help tell the story. Newspaper that is published daily makes it possible to present actual news, which is the subject of public discussion at the time, and can be easily documented as a media of analysis.

Several aspects are examined to assess the relationship between the media and female politicians, especially how the media frames and treats female politicians in their coverage. The use of several different types of media as research subjects and the use of diverse analytical methods can produce a more comprehensive research.

In general, there is no difference between the media in American and European countries, which have a high index of press freedom, and the media in African and Asian countries whose index of press freedom is low, in applying standards to the coverage of female and male politicians. In these countries, the media still applies different standards between men and women, and does not take a neutral attitude towards women politicians. Even though the media in the United States and Europe gives increasing space to women, the European press culture is still dominated by men. Meanwhile, the space given to female politicians in African and Asian countries is very minimal.

The media, when portraying women politicians, does not make competencies, vision, and programs as an attraction that needs to be displayed to the public to know. The media in Europe uses conventional standards of attraction in the same way as the media in Africa and Asia, focusing their coverage of female politicians not on their intellectual substance, but rather on their gender and womanhood. Women are described as non-serious police officers. In Asia, women are not portrayed as politicians, but as fashion celebrities, being not serious, and lacking political ability.

\section{CONCLUSION}

The research using this meta-analysis shows that the discourse on fair treatment of women is not only a domain of countries in Asia and Africa that are identical to democratic systems that are not yet established and even authoritarian, but in American and European countries which are in fact mature in democracy which guarantees egalitarian and equal rights of citizens, regardless of gender, also still resonates. The question of fairness of gender-based treatment is not only addressed to 'ordinary' women but also to women who are involved in politics. 
The media is one of the tools serving as a benchmark to assess whether equal treatment of male and female politicians has occurred, or whether the differential treatment gap between male and female politicians has narrowed. The assessment was conducted by observing how the media treats and frames women politicians.

The media, both in countries that have established democratic systems such as America and Europe and in countries that are not yet democratically established such as Africa and Asia, are no different in treating, framing and applying standards in their coverage of women politicians. Women politicians are presented by the media in terms of gender and femininity as well as the female side, while the ability, strength of vision, and competence in the political field are very minimal to be covered by the media.

Referring to the description and observable indications, it can be concluded that the portrait of women politicians in the frame of the mass media is still blurred without any clear differences in American, European, African and Asian countries.

Based on these conclusions it is recommended that improvements be made to women's self-concept. This must be done in a measurable and sustainable manner. In the results of his research, Umaimah (2013) also emphasized the need for women to make genuine efforts to strengthen themselves and improve their quality so that they can reduce the dominance of a community group.

It is also recommended that editors-in-chief and journalists get involved more actively to build common perceptions of the need to place women politicians in the right portion according to their abilities. This is important so that the media has real responsibility and contribution through the coverage and news it publishes. Editors-in-chief and journalists need to be well acquainted with symbols that can be interpreted as gender biases in the characteristics of women. Napat Ruangnapakul and Norsiah Abdul Hamid's research shows that the aspect of mise-en-scène in films constantly uses red in the scenes of the main female characters to show self-confidence, innocence, or high sexual attractiveness of women. Moreover, the red color is also used to reflect male sexual desires (Napat \& Norsiah, 2017, p.159).

\section{BIODATA}

Hasan Sazali is a lecturer at Universitas Islam Negeri Sumatera Utara, Indonesia. Email: hasansazali@uinsu.ac.id

Lutfi Basit is a lecturer at University of Muhammadiyah Sumatera Utara and student at Postgraduate Program Universitas Islam Negeri Sumatera Utara, Indonesia. Email: lutfibasit@umsu.ac.id 


\section{REFERENCES}

2019 World Press Freedom Index. (2019). Retrieved from https://rsf.org/en/ranking, accessed on 7 August 2019.

Astuti, M. (2016). Konstruksi sosial media terhadap kekuatan personal branding Tri Rismaharini dalam proses komunikasi politik kontemporer. Jurnal Dakwah dan Komunikasi, 1(1). E-ISSN: 2548-3366.

Azmawati, A. A. (2017). Women, politics and the media. Int J Journalism Mass Comman, 4, 126.

Beijing platform for action: 12 critical areas of concern. (2015). Retrieved from https://asiapacific.unwomen.org/en/news-and-events/stories/2015/03/b20-12critical-areas-of-concern. Accessed on 7 August 2019.

Campus, D. (2013). Women political leaders and the media. England: Palgrave Macmillan.

Chang, C., \& Hitchon J. (1997). Mass media impact on voter response to women candidates: Theoretical development. Communication Theory, 7(1), 29-52.

Council of Europe. (2017). Study on media coverage of elections with a specific focus on gender equality. Committee of experts on Media Pluralism and Transparency of Media Ownership (MSI-MED). MSI-MED (2016) 11 rev 5, 7 December 2017. Retrieved from https://rm.coe.int/study-gender\%20-equality-in-media-coverage-of-elections/ 1680776164.

Damean, D. (2006). Media and gender: Constructing feminine identities in a post modern culture. JSRI, 14(Summer), 90.

Democracy Index 2018. (2019). Retrieved from https://www.eiu.com/topic/democracy-index Fauzi, A. C. (2007). Kabar-kabar kekerasan dari Bali (24). Yogyakarta: LkiS.

Fernandez-Garcia, N. (2016). Framing gender and women politicians representation: Print media coverage of spanish women ministers. In C. Cerqueira, R. Cabecinhas \& S. I. Magalhães (Eds.), Gender in focus: (New) trends in media (pp. 141-160). Braga: CECS.

Fitriyah, N., Sarwoprasodjo, S., Sjaf, S., Soetarto, E., (2019). Interaksi politik Jawara dalam pembangunan perspektif tindakan komunikasif. Warta Ikatan Sarjana Komunikasi Indonesia, 2(2), 104-116.

Foucault, M. (1997). Ethics: Subjectivity and truth (The essential works of Michel Foucault, 1954-1984, Vol. 1) (Ed. by P. Rabinow, Trans by R. Hurley). New York: New Press.

Fountaine, S., \& McGregor, J. (2002). Reconstructing gender for the 21st century: News media framing of political women in New Zealand. Australian \& New Zealand Communication Association 23rd Annual Conference 2002, Coolangatta, Queensland.

Fox, C. (2010). Bound: Print journalism's framing of female candidates in the 2008 presidential race according to the 'double bind' theory. The Elon Journal of Undergraduate Research in Communications, 1(2).

Gershon, S. A. (2012). Media coverage of minority congresswomen and voter evaluations: Evidence from an online experimental study. Political Research Quarterly, 66(3), 702714. https://doi.org/10.1177/1065912912467851

Hirdman, Y. (1990). Demokrati och makt i Sverige: Maktutredningens huvudrapport (44, pp. 73-114). Statens Offentliga Utredningar (SOU). Stockholm: Allmänna förl. Retrieved from https://lagen.nu/sou/1990:44

Ihechu, I., \& Okugo, C., Amah, F., \& Afulike, C. (2017). Media coverage and framing of cultural practices that target Nigerian women. Covenant Journal of Communication, 4(2). 
Islam, S. M. S. (2016). Coverage bias of Bangladesh television media: A portrayal of power and politics. Jurnal Komunikasi: Malaysian Journal of Communication, 32(2), 240-258.

Johnson, T. B. (2017). Waves of feminism and the media. Lewis Honors College Capstone Collection, 32.

Kahn, K. F. (1994). The distorted mirror: Press coverage of women candidates for statewide office. The Journal of Politics, 56(1), 154-173.

Kaul, V. (2012). Globalization and gender issue. Jurnal Komunikasi: Malaysian Journal of Communication, 28(2), 173-203.

Kumar, P. (2017). Participation of women in politics: Worldwide experience. IOSR Journal of Humanities and Social Science (IOSR-JHSS), 22(12), Ver. 6 (December 2017), 77-88.

Kumari, A., \& Joshi, H. (2015). Gender stereotyped portrayal of women in the media: Perception and impact on adolescent. IOSR Journal of Humanities and Social Science (IOSR-JHSS), 20(4), Ver. II (Apr. 2015), 44-52.

Lee, J., \& Lee, K. (2016). Gendered reactions to women politicians in Japan: The role of media use and political cynicism. Keio Communication Review No.38, 21-38.

Lundell, A. K., \& Ekström, M. (2008). The complex visual gendering of political women in the press. Journalism Studies, 9(6), 891-910. https://doi.org/10.1080/14616700802227845

Matingo, E., \& Edson, M. (2012). Media representation of women in politics (October 1 to November 30, 2012). Media monitoring project Zimbabwe.

McLuhan, M. (1964). Understanding media: The extensions of man (1st ed.). New York: McGraw Hill; reissued by MIT Press, 1994; Corte Madera, CA: reissued by Gingko Press, 2003.

McNair, B. (1995). An introduction to political communication. London: Routledge.

McQuail, D. (2005). McQuail's mass communication theory (5th ed.). London: SAGE.

Munir, S., Shehzad, H., \& Sahi, A. (2014). Media analysis of women's participationin politics. Journal of Mass Communication \& Journalism, 4(3). https://doi.org/10.4172/21657912.1000183

Napat Ruangnapakul, \& Norsiah Abdul Hamid. (2017). Lady in red: Framing the representation of women through mise-en-scène. Jurnal Komunikasi: Malaysian Journal of Communication, 33(4), 159-173.

Norris, P. (1997). Women, media, and politics. New York: Oxford University Press.

Oyewole, J. A., \& Olisa, D. S. (2017). Media, politics and gender marginalisation in Nigeria: Is there still a way out?. International Journal of Media Journalism and Mass Communications (IJMJMC), 3(1), 20-26. http://dx.doi.org/10.20431/24549479.0301003

Rahman, B. H., Eijaz, A., \& Ahmad, R. E. (2015). Framing of women in politics: A case of Pakistani elections 2013. Journal of Political Studies, 22(1), 335- 350.

Rahman, B. H. (2010). Analysis of the coverage of Muslim political women in Time and Newsweek. Journal of Media Studies, 25(1).

Rajaratnam, U. D., \& De Rycker, A. (2018). From gender stereotyping to constructing political identity: Changes in Malaysiakini's portrayal of women candidates during Malaysia's 2008 and 2013 general elections. Jurnal Komunikasi: Malaysian Journal of Communication, 34(1), 218-237.

Ritonga, R., Murwani, E., \& Ritonga, S. (2018). Gender awareness of maria hartiningsih as Daily Kompas reporter. Jurnal Komunikasi Ikatan Sarjana Komunikasi Indonesia, 2(2), 82-91. 
Scheufele, D. A., \& Iyengar, S. (2014). The state of framing research: A call for new directions. In K. Kenski \& K. H. Jamieson (Eds.), The Oxford handbook of political communication theories. New York, NY: Oxford University Press. https://doi.org/10.1093/oxfordhb/9780199793471.013.47

Stellarosa, Y. (2017). Woman image in "Miss Jinjing belanja sampai mati" book. Jurnal Komunikasi Ikatan Sarjana Komunikasi Indonesia, 2(02), 97-108.

Topic, M., \& Gilmer, E. C. (2017). Hillary Clinton and the media: From expected roles to the critique of feminism. The Qualitative Report, 22(10), 2533-2543.

Tuchman, G. (1978). The symbolic annihilation of women by the mass media. In G. Tuchman, A. K. Daniels \& J. Benet (Eds.), Hearth and home: Images of women in the mass media. New York: Oxford University Press.

Umaimah, W. (2013). Perempuan dan kekuasaan politik dalam Pemilukada DKI Jakarta tahun 2012. Jurnal Komunikasi: Malaysian Journal of Communication, 29(1), 73-97.

Van Zoonen, L. (2006). The personal, the political and the popular: A woman's guide to celebrity politics. European Journal of Cultural Studies, 9(3), 287-301. https://doi.org/10.1177/1367549406066074

Zamroni, M. (2013). Perempuan dalam kajian komunikasi politik dan gender. Jurnal Dakwah, $\operatorname{XIV}(1)$. 